\title{
Outpatient Satisfaction at Private General Hospitals in Ho Chi Minh City, Vietnam
}

\author{
Ha Nam Khanh GIAO ${ }^{1}$, Nguyen Thi Anh THY ${ }^{2}$, Bui Nhat VUONG ${ }^{3}$, Truong Van KIET ${ }^{4}$, Le Thi Phuong LIEN \\ Received: May 13, 2020 Revised: May 17, 2020 Accepted: June 10, 2020
}

\begin{abstract}
The quality of hospital services remains a concern of both the manager and the patient. The study aims to identify factors affecting outpatient satisfaction at private general hospitals in Ho Chi Minh City, establishing a scale for measuring them. Some 450 outpatients who were treated in five top private hospitals in Ho Chi Minh city (HCMC) in 2019 - An Sinh General Hospital, Hoan My General Hospital, Columbia Asia International Hospital, FV Hospital, and Vu Anh International General Hospital - were interviewed directly in the last quarter of 2019 to obtain the information. The SERVPERF model, plus the cost, together with the SPSS software, have been used to process information by Cronbach's alpha analysis, Exploratory Factor analysis, and linear regression analysis. The results show that there are five factors influencing outpatient satisfaction at private general hospitals in HCMC, in which four factors affects positively in the order of decreasing importance: treatment outcome, doctors and nurses' professional capacity, facilities and environment of the hospital, hospital care, and the treatment time factor affects negatively. The results of the study provide private hospital in HCMC managers with a number of suggestions to increase the level of hospital service quality, so that increase outpatients satisfaction.
\end{abstract}

Keywords : Ho Chi Minh City, Outpatients Satisfaction, Private General Hospital, Vietnam

JEL Classification Code: C12, C83, I11, I12, M31

\section{Introduction}

Many studies have shown that satisfaction of service recipients is a good condition for maintaining a long-term relationship with a service provider (Cronin, Brady, \& Hult,

${ }^{1}$ First Author and Corresponding Author. Dean, Faculty of Air Transport, Vietnam Aviation Academy, Vietnam [Postal Address: A65 Nam Thong 1 Town, Phu My Hung Zone, Tan Phu Ward, District 7, Ho Chi Minh City, 72908, Vietnam] Email: khanhgiaohn@yahoo.com

2Deputy Chief, Department of Finance and Accounting, Vietnam

Aviation Academy, Vietnam. Email: thynta@vaa.edy.vn

${ }^{3}$ Lecturer, Faculty of Air Transport, Vietnam Aviation Academy,

Vietnam. Email: nhatvuong1@gmail.com

${ }^{4}$ Doctoral Student, Tra Vinh University, Vietnam. Email: truongvankiett@yahoo.com

${ }^{5}$ Deputy Chief, Foreign Languages - Informatics Center, University of Banking, Vietnam. Email: phuongliendhnh@gmail.com

(c) Copyright: The Author(s)

This is an Open Access article distributed under the terms of the Creative Commons Attribution Non-Commercial License (http://Creativecommons.org/licenses/by-nc/4.0/) which permits unrestricted noncommercial use, distribution, and reproduction in any medium, provided the original work is properly cited.
2000; Choi, Cho, Lee, Lee, \& Kim, 2004; Anderson, Fornell, \& Lehmann, 2004; Sweeney, Dagger, \& Johnson, 2007). On the medical side, the World Health Organization (WHO, 2000) states that patients who are satisfied will cooperate more closely to monitor and implement regimens. Over the past decade in Vietnam, research on patient satisfaction has been rare; hospital managers often rely on experience to make decisions that improve patient satisfaction.

Since the mid-1990s, the Government has advocated for the socialization of healthcare in order to mobilize many resources of society to invest in the field of people's healthcare. Private hospitals are established and are defined as a conditional business establishment set up under the Enterprise Law, and must comply with the Ordinance on Private Medical Practice and Health Act. At the end of 2019, Vietnam has 248 private hospitals (out of 1,365 in total, not accounted hospitals under the Department of Defense management) with 21,048 clinics all over 63 provinces and big cities (Vietnam+, 2020).

HCMC has many medical facilities with diversified operations; the city health sector not only serves the people in the area, but also serves the people in the southern provinces, 
and people from nearby countries such as Laos and Cambodia. HCMC has 128 hospitals, accounting for $9.38 \%$ of the whole country, of which 82 public hospitals including general and specialized hospitals, accounting for $64.1 \%$ and 46 private hospitals, accounting for $35.9 \%$ (Department of HealthHCMC, 2020a). Many hospitals in the city are large-scale with modern medical equipment, a team of doctors, specialized in modern techniques to bring high results in medical examination. Therefore, hospitals in the city always attract patients from all southern provinces. In the general condition of the health sector, some of the city's public hospitals continue to suffer from overcrowding, so that private hospitals grow their own markets in recent years.

At the end of 2019 , especially the $11^{\text {th }}$ and $12^{\text {th }}$ of December, Department of Health HCMC conduct a survey through 110 hospitals in $\mathrm{HCMC}$ to analyze the service quality of the hospitals in HCMC by the determinants developed by Department of Health years before (Department of Health HCMC, 2020b). The result was helpful to the hospitals management; however, the nature of the survey and analysis is from the management side, so there is still a need for a deep analysis from the patient side, especially for the private hospitals in HCMC, so this research does that.

\section{Literature Review}

\subsection{Quality Service and Customer Satisfaction}

Many scholars paid attention to services in general and service quality in particular. Quality of service, as a concept, raises a high interest of scientists and researchers, as the quality of service is not only difficult to define, but to measure as well (Zeithaml \& Bitner, 2000; Parasuraman, Zeithaml \& Berry, 1985, 1988, 1994; Gronroos, 1984; Giao, Hang, Phuong, Vuong, Tuan, Vinh, \& Tu, 2020; Giao, Hoai \& Vinh, 2019; Giao, 2004, 2018b, 2019; Oliver, 1981). The main definitions of quality of service focus on the fact that the service has to meet the customer's needs and expectations (Liu \& Xie, 2013; Breja, Banwet, \& Iyer, 2011) and is interpreted as a difference of terms of service provision and customers' expectations of perceived service. If the customer's expectations are higher than the result of the service process, then customer perceived service quality is not satisfactory (Huang, Wang, \& Xue, 2012). Most of the research is about personal services (Vuong \& Giao, 2019; Giao \& Ai, 2012; Giao \& Lien, 2018; Giao \& Mo, 2018; Giao, Vuong, Huan, Tushar \& Quan, 2020; Giao, 2017; Giao, Vuong \& Quan, 2018; Giao, Duong \& Tu, 2018; Giao, Hoang \& Vinh, 2018), not so much research is about business services (Giao, Trung \& Truong, 2019; Giao, 2018a, Bartels, Giao \& Ohlenburg, 2006).

Zeithaml and Bitner (1996) defined services as behaviors, processes, and ways of working to create value for customers. Thus, the service has features that distinguish it from tangible products. Kotler and Armstrong (2004) argued that services are activities or benefits that businesses can offer to customers to establish, strengthen and extend longterm relationships and partnerships with customers. Services characteristics are intangibility, heterogeneity/variability, perishability, and inseparability. There are different views on the quality of service, but the service is dedicated to customer service, so the quality of service viewed from the perspective of customers is very interested by business managers and researchers. Grönroos (1984) identified three components - technical, functional and reputational quality. Functional quality is considered as the process of service and technical quality is considered to be the result of the service. Grönroos (1998) explained customer expectation as a promise from the market, company image, word of mouth, and customer demand. The most common service quality measurement tool, SERVQUAL, was introduced by Parasuraman, Zeithaml, and Berry (1985) and revised in 1988. SERVQUAL is based on the distance between Perceived quality of service $(\mathrm{P})$ and Expected quality of service $(\mathrm{E})$, service quality $(\mathrm{Q})$ is calculated as the difference between $\mathrm{P}$ and $\mathrm{E}(\mathrm{Q}=\mathrm{P}-\mathrm{E})$. SERVQUAL service quality model and scale (Parasuraman et al, 1988) have been used to measure service quality in many different areas such as dental (Carman, 1990), hospital (Babakus \& Mangold, 1992), higher education (McElwee \& Redman, 1993), auditing services (Freeman \& Dart, 1993), architectural services (Baker \& Lamb, 1993), banking services (Spreng \& Singh, 1993).

Many researchers cited one of the definitions of customer satisfaction as Oliver's definition (1981): satisfaction is the result of an emotional state, which reflects the expectations satisfied through the consumer experience that consumers feel. According to Kotler and Amstrong (2004), satisfaction is the level of a person's sense that results from comparing the results obtained from the product when compared to his or her expectations. In addition to service-quality research from customer perception, customer satisfaction measurement has been debated over many decades. In their study of service quality, Parasuraman et al. (1985, 1988) measured customer satisfaction, but the prefixes of satisfaction were not specified. Dabholkar (1995) found in empirical studies that satisfaction and quality of service are two distinct constructs in a short period of time, but there is a convergence of satisfaction and quality of service when consumers regularly use the service for a long time.

Cronin and Taylor (1992) conducted empirical research and found that perceived quality leads to satisfaction. Zeithaml, Berry, \& Parasuraman (1993) explained: "Satisfaction is the difference that comes from the evaluation of service quality." Teas (1993) argued based on the concept that satisfaction is a function of service quality, which 
derives from customer perception on a particular transaction. From this important observation, Parasuraman et al (1994) developed two structures of satisfaction in both contexts: (1) in a particular transaction and (2) in all transactions. Satisfaction in a particular transaction means satisfaction "here and now" (Gronroos, 1998), while the satisfaction in all transactions is derived from the accumulation of each transaction through time. Parasuraman et al. (1994) added in the model two more factors affecting satisfaction: product quality and price. At the same time, Parasuraman et al (1994) exemplified the customer satisfaction model for a company through the accumulation of numerous transactions.

\subsection{Health Care Services and Patient Satisfaction}

Health care is essentially a service, so service quality and customer satisfaction theories can be applied to the healthcare field. The medical environment is influenced by the law of supply and demand as well as the regulation of the state, and is always dominated by traditional values. There are two types of services: inpatient and outpatient. It depends on the target and the research target for which the scope of the service is focused on the care process or outcome, or both. Various studies have shown that the components of the quality scale of health care are a combination of SERVQUAL models (Parasuraman et al., 1985, 1988) and Grönroos (1983).
Factors affecting patient satisfaction from research findings by marketing researchers and medical literature are also consistent with the satisfaction model of Parasuraman et al. (1994) and Zeithaml et al. (1996), including: quality of service, cost, personal factors and situational factors in which quality has the most significant impact. Andaleeb, Siddiqui, and Khandakar (2007) put the hypotheses from each attribute of the quality of treatment directly influencing the satisfaction of the patient and the researchers have found some meaningful models. Currently, many studies were conducted in health care services (Choe et al., 2012, Hau et al., 2016, Ranjbar et al., 2012, Solayappan et al., 2011, Meesala \& Paul, 2018, James et al., 2017, Vogus \& McClelland, 2016, Mitropoulos, 2018), remarkably Lee (2017) suggested HEALTHQUAL model consisting of five components: empathy, tangibles, safety, efficiency, and degree of improvements of care service.

From these theoretical outlines, the theoretical model of outpatient satisfaction is shown in Figure 1. The objective of this study is not to measure high or low quality, high cost or low cost, but to focus on the causal relationship between factors and outpatient satisfaction. Thus, based on the view of Cronin and Taylor (1992), Teas (1993) and Zeithaml etal. (1993), the expectation is not measured, but only measured the patient's perception through a specific treatment. And in the manner of Andaleeb et al. (2001, 2007), the elements of the quality scale are directly linked to satisfaction.

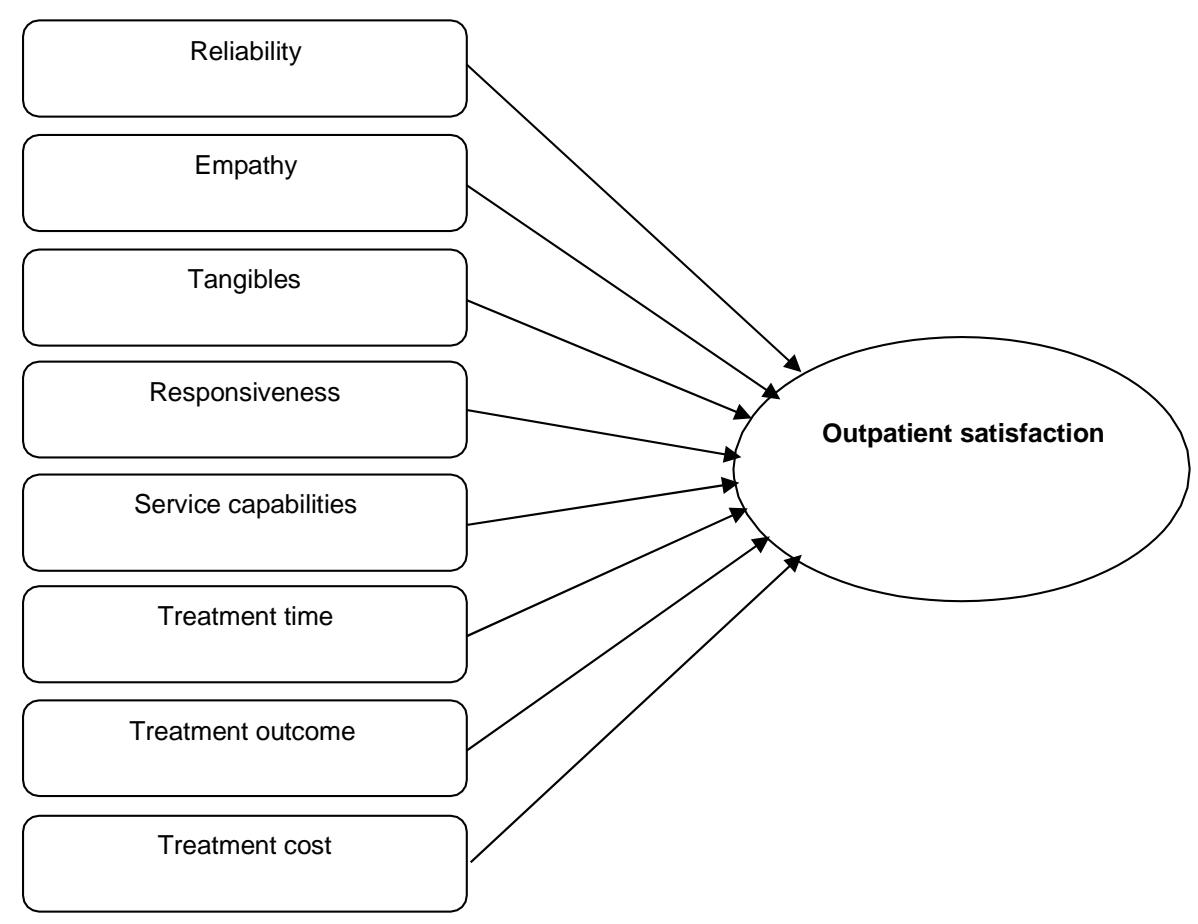

Figure 1: Suggested study model 


\section{Methodology}

By interviewing 10 outpatients with nine in-depth interview questions and a number of flexible questions in each case, the outpatients' opinions were very useful. Through interviews, highlighting the details that every outpatient is concerned about is the role of the doctors during outpatient visits and treatment. Through in-depth interviews, the "results" component satisfies the outpatient's desire not merely to improve the health status of an outpatient after treatment, but also to determine the outcome of medical examination. In addition, the time of medical examination is an important factor; the length of medical treatment has a negative impact on the psychology of outpatients. Thus, together with components such as reliability, empathy, tangibles, responsiveness, service capabilities, and medical cost, this study proposes a "treatment outcome" and "treatment time" into the suggested model of outpatient satisfaction (Figure 1).

This research was conducted to identify factors affecting outpatient satisfaction of the service quality at private hospitals in HCMC. A total of 450 outpatients who were treated in five top private hospitals in HCMC - An Sinh General Hospital, Hoan My General Hospital, Columbia Asia International Hospital, FV Hospital, and Vu Anh International General Hospital - were interviewed directly in the last quarter of 2019. The SERVPERF model, together with a combination of quantitative and qualitative research, has been used to process information. Stratified sampling was chosen, and the respondents are the outpatients who are treated at least once at the hospitals. The expected results are to measure the impact of the factors to outpatient satisfaction of the service quality of the hospitals in HCMC. In turn, these factors become the basis for suggestions to improve the outpatient satisfaction.

\section{Research Results}

\subsection{Sample Description}

Samples obtained meet the sampling requirements using a stratified sampling method based on the hospitals and diseases. The survey was conducted in the last quarter of 2019; the interviews were conducted directly to the outpatients who are waiting time for treatment at the hospitals. The characteristics of 450 observation samples are shown in Tables 1.

\subsection{Evaluation of the Scale by Cronbach's Alpha}

In the full sample with $\mathrm{n}=450$, nine scales have a Cronbach's alpha of 0.7 and the item - total correlations are greater than 0.3 (Table 2). Thus, the scales are reliable and all the observational variables are further used in the exploratory factor analysis.

\subsection{Exploratory Factor Analysis - EFA}

The coefficient KMO $=0.912$ and Bartlett's test for significance less than 0.01 , which is necessary and sufficient to analyze the exploratory factor. The factor analysis on the sample $n=450$ with the principal component extraction method and the perpendicular rotation resulted in seven factors being extracted and each component factor had a higher factor loadings of 0.5 (Table 3 ). Of the seven factors, four factors are unchanged: tangible means, treatment outcome, treatment time and treatment cost. The components of the three factors: "responsiveness", "empathy" and "service capabilities" have been rearranged to form Factor 2 and Factor 4. All seven factors have Eigenvalues, which are greater than 1 and a total variance of $68.8 \%$, both of which meet the requirement for factor analysis (Giao \& Vuong, 2019). New factors were recalculated using Cronbach's alpha, and all factors have Cronbach's alpha greater than 0.7 .

In order to carry out the regression analysis, components were renamed to fit the elements in each factor, and the research model was modified with new names or new factors in place of an original element.

Factor 1: Facilities and hospital environment, notated as TAN

1. The appearance of the hospital looks very beautiful

2. The staff's clothes are neat and clean

3. Hospitals are always clean and neat

4. Patients easily find the office room such as: doctor room, laboratory room, x-ray room, ultrasound room,...

5. The hospital seems to have modern medical equipment

6. Waiting room for medical examination and waiting for medicine are always fresh

Factor 2: Doctors and nurses' professional capacity, notated as PRO

1. The doctor examines the patient very carefully (eg, examining, observing, listening to the heart, and examining others for a diagnosis ...)

2. The doctor consults the patient before appointing the test, x-ray, ultrasound, minor surgery. . .

3. Doctors seem to have a lot of experience.

4. The doctor clearly answers the patient's questions about the condition.

5. The doctor clearly explains the result of the examination, treatment and return.

6. Doctors are concerned about what the patient is most worried about 
Table 1: General information about the sample

\begin{tabular}{|c|c|c|c|}
\hline \multirow{2}{*}{\multicolumn{2}{|c|}{ Characteristics }} & \multicolumn{2}{|c|}{ Sample $(n=450)$} \\
\hline & & Frequency & Percentage \\
\hline Treatment location & $\begin{array}{l}\text { An Sinh General Hospital } \\
\text { Hoan My General Hospital } \\
\text { Columbia Asia International Hospital } \\
\text { FV Hospital } \\
\text { Vu Anh International General Hospital }\end{array}$ & $\begin{array}{l}90 \\
90 \\
90 \\
90 \\
90\end{array}$ & $\begin{array}{l}20 \\
20 \\
20 \\
20 \\
20\end{array}$ \\
\hline Gender & $\begin{array}{l}\text { Male } \\
\text { Female }\end{array}$ & $\begin{array}{l}191 \\
259\end{array}$ & $\begin{array}{l}42.44 \\
57.56\end{array}$ \\
\hline Age & $\begin{array}{l}20 \text { to less than } 30 \\
30 \text { to less than } 39 \\
40 \text { to less than } 50 \\
50 \text { to less than } 60 \\
60 \text { or more }\end{array}$ & $\begin{array}{l}133 \\
63 \\
68 \\
41 \\
39\end{array}$ & $\begin{array}{l}29.56 \\
14.00 \\
15.11 \\
9.11 \\
8.67\end{array}$ \\
\hline Education & $\begin{array}{l}\text { Primary school } \\
\text { Secondary school } \\
\text { High school } \\
\text { Vocational school } \\
\text { College and post-graduate }\end{array}$ & $\begin{array}{c}38 \\
171 \\
151 \\
62 \\
28\end{array}$ & $\begin{array}{c}8.44 \\
38.00 \\
33.56 \\
13.78 \\
6.22\end{array}$ \\
\hline Occupation & $\begin{array}{l}\text { Officer } \\
\text { Staff, teachers } \\
\text { Technician } \\
\text { Business people } \\
\text { Worker } \\
\text { Retire } \\
\text { Housewife } \\
\text { Other occupations }\end{array}$ & $\begin{array}{c}7 \\
61 \\
19 \\
75 \\
167 \\
64 \\
30 \\
27\end{array}$ & $\begin{array}{c}1.56 \\
13.56 \\
4.22 \\
16.67 \\
37.11 \\
14.22 \\
6.67 \\
6.00\end{array}$ \\
\hline Income & $\begin{array}{l}\text { Under } 5 \text { million Vietnam Dong (VND) } \\
\text { From } 5 \text { to under } 10 \text { million VND } \\
\text { From } 10 \text { to less than } 20 \text { million VND } \\
\text { From } 20 \text { to under } 40 \text { million VND } \\
\text { From } 40 \text { million VND up } \\
\text { No income }\end{array}$ & $\begin{array}{c}97 \\
230 \\
82 \\
17 \\
15 \\
9\end{array}$ & $\begin{array}{l}21.56 \\
51.11 \\
18.22 \\
3.78 \\
3.33 \\
2.00\end{array}$ \\
\hline Health insurance & $\begin{array}{l}\text { Treatment with health insurance } \\
\text { Treatment without health insurance }\end{array}$ & $\begin{array}{l}191 \\
259\end{array}$ & $\begin{array}{l}42.44 \\
57.56\end{array}$ \\
\hline
\end{tabular}

Table 2: Cronbach's alpha of the scales $(n=450)$

\begin{tabular}{|l|l|c|c|c|c|}
\hline No & \multicolumn{1}{|c|}{ Scale } & Notation & $\begin{array}{c}\text { No of } \\
\text { observed } \\
\text { variables }\end{array}$ & $\begin{array}{c}\text { Cronbach's } \\
\text { Alpha }\end{array}$ & $\begin{array}{c}\text { Smallest item - } \\
\text { total correlation }\end{array}$ \\
\hline 1 & Tangibles & TAN & 6 & 0.868 & 0.563 \\
\hline 2 & Reliability & REL & 3 & 0.776 & 0.601 \\
\hline 3 & Responsiveness & RES & 3 & 0.786 & 0.501 \\
\hline 4 & Empathy & EMP & 4 & 0.813 & 0.607 \\
\hline 5 & Service capabilities & ASS & 5 & 0.847 & 0.624 \\
\hline 6 & Treatment outcome & OUT & 4 & 0.843 & 0.422 \\
\hline 7 & Treatment time & TIME & 3 & 0.870 & 0.688 \\
\hline 8 & Treatment cost & COST & 3 & 0.802 & 0.566 \\
\hline 9 & Outpatient satisfaction & SAT & 4 & 0.862 & 0.676 \\
\hline
\end{tabular}


Table 3: Exploratory Factor Analysis $(n=450)$

\begin{tabular}{|c|c|c|c|c|c|c|c|}
\hline Variable & Factor 1 & Factor 2 & Factor 3 & Factor 4 & Factor 5 & Factor 6 & Factor 7 \\
\hline $\mathrm{TAN}_{3}$ & 0.796 & & & & & & \\
\hline $\mathrm{TAN}_{2}$ & 0.787 & & & & & & \\
\hline $\mathrm{TAN}_{6}$ & 0.750 & & & & & & \\
\hline TAN $_{1}$ & 0.737 & & & & & & \\
\hline $\mathrm{TAN}_{4}$ & 0.679 & & & & & & \\
\hline $\mathrm{TAN}_{5}$ & 0.610 & & & & & & \\
\hline $\mathrm{EMP}_{1}$ & & 0.653 & & & & & \\
\hline $\mathrm{EMP}_{3}$ & & 0.647 & & & & & \\
\hline $\mathrm{RES}_{3}$ & & 0.634 & & & & & \\
\hline ASS2 & & 0.615 & & & & & \\
\hline $\mathrm{EMP}_{2}$ & & 0.597 & & & & & \\
\hline $\mathrm{ASS}_{3}$ & & 0.583 & & & & & \\
\hline ASS $_{1}$ & & 0.550 & & & & & \\
\hline $\mathrm{REL}_{3}$ & & 0.508 & & & & & \\
\hline $\mathrm{OUT}_{1}$ & & & 0.79 & & & & \\
\hline $\mathrm{OUT}_{4}$ & & & 0.75 & & & & \\
\hline $\mathrm{OUT}_{2}$ & & & 0.64 & & & & \\
\hline $\mathrm{OUT}_{3}$ & & & 0.57 & & & & \\
\hline $\mathrm{RES}_{2}$ & & & & 0.798 & & & \\
\hline $\mathrm{RES}_{1}$ & & & & 0.730 & & & \\
\hline $\mathrm{EMP}_{4}$ & & & & 0.701 & & & \\
\hline $\mathrm{ASS}_{4}$ & & & & 0.636 & & & \\
\hline $\mathrm{ASS}_{5}$ & & & & 0.631 & & & \\
\hline $\mathrm{TIME}_{3}$ & & & & & 0.934 & & \\
\hline TIME $_{1}$ & & & & & 0.850 & & \\
\hline $\mathrm{TIME}_{2}$ & & & & & 0.843 & & \\
\hline $\mathrm{REL}_{2}$ & & & & & & 0.87 & \\
\hline $\mathrm{REL}_{4}$ & & & & & & 0.79 & \\
\hline $\mathrm{REL}_{1}$ & & & & & & 0.69 & \\
\hline $\mathrm{COST}_{2}$ & & & & & & & 0.87 \\
\hline $\mathrm{COST}_{1}$ & & & & & & & 0.85 \\
\hline $\mathrm{COST}_{3}$ & & & & & & & 0.75 \\
\hline
\end{tabular}


7. Nursing counseling for patients with peace of mind before taking blood test, x-ray, ultrasound, minor surgery. . .

8. Nurses are well versed in performing medical procedures.

Factor 3: Treatment outcome, notated as OUT

1. The patient's health has improved over the course of the treatment.

2. Patient trust the medical profession will bring high efficiency

3. Patients trust the hospital's medical machinery for accurate results

4. Patients believe the hospital has brought the best treatment outcome

Factor 4: Hospital care, notated as CARE

1. When the patient needs, the hospital staff are available to help

2. The hospital staff are happy to guide patients on where to go and what to do

3. Simple and accurate administrative procedures (checkin, bill payment)

4. Hospital staff treats patients very well.

5. Patients feel secure when communicating with hospital staff.

Factor 5: Treatment time, notated as TIME

1. Patients have to wait too long at some stages of the hospital (eg, registration of the examination, waiting for the doctor to wait for the results of the test)

2. The communication time between the doctor and the patient is too small

3. Patients spend too much time for a medical examination

Factor 6: Patients' reliability on the hospital, notated as REL

1. The hospital ensures the patient's privacy (eg, confidential clinics, medical information exchanged with the physician)

2. The hospital always performs tasks on time

3. The file is free of errors (for example: medical records, results card, prescriptions, invoices)

Factor 7: Cost of treatment, notated as COST

1. The cost of medical treatment exceeds the cost that the patient can pay.

2. The cost of medical examination and treatment is higher than the patient's estimated cost.

3. The cost of medical examination and treatment at hospitals is reasonable.

EFA of the dependent variable group showed that KMO and Bartlett's in the analysis of factors have sig. $=0.000$ and $\mathrm{KMO}=0.801>0.5$; The Eigenvalue value is $2.942>$ 1. Therefore, the extracted scales are acceptable. All four observed variables have factor loadings, which are greater than 0,5 . Thus, the scale satisfies the convergence value and reliability (Giao \& Vuong, 2019), and was described in Table 4.
Table 4: EFA results of the service quality satisfaction scale

\begin{tabular}{|c|c|}
\hline & Factor loading \\
\cline { 2 - 2 } & $\mathbf{1}$ \\
\hline $\mathrm{SAT}_{3}$ & 0.822 \\
\hline $\mathrm{SAT}_{4}$ & 0.834 \\
\hline $\mathrm{SAT}_{2}$ & 0.851 \\
\hline $\mathrm{SAT}_{1}$ & 0.825 \\
\hline
\end{tabular}

\subsection{Correlation Analysis}

Table 5 shows that, with the exception of the cost variable $(\mathrm{COST})$, the variables in the regression model are significantly correlated at less than 0.05. Correlation coefficient between variables is less than 0.85 , it can be said that the independent variables in the model guarantee distinct values.

\subsection{Linear Regression Analysis}

The linear regression model followed the Enter method, the dependent variable was satisfaction and the six independent variables. The REL was not statistically significant $(\mathrm{Sig}=0.253$ ). The final linear regression model (Table 6) has a value of $F=165.7$, corresponding to a significance level less than 0.001 . Independent variables are less than 0.01 and all have a partial correlation with the dependent variable. This model accounts for $65.9 \%$ of the variance of the dependent variable due to the effect of the five independent variables.

Unstandardized regression equation is as follows:

$$
\begin{aligned}
& \mathrm{SAT}=-0.231+0,209 * \mathrm{TAN}+0,209 * \mathrm{PRO}+0,297 * \\
& \mathrm{OUT}+0,346 * \mathrm{CARE}-0,093 * \mathrm{TIME}
\end{aligned}
$$

From standardized regression model, it is found that factors affecting outpatient satisfaction are in reducing importance order: treatment outcome $(\beta=0.315)$, doctors and nurses' professional capacity $(\beta=0.269)$, hospital facilities and environment $(\beta=0.196)$, hospital care $\beta=(0.178)$, and treatment time $(\beta=-0.093)$. The results of this study have similarities with the results of some studies in Asian countries (Linh et al, 2002, Choi et al., 2004, Andeleeb et al., 2007, Ranjbar et al., 2012), such as: (1) tangibles, (2) service of doctors, (3) service of other employees. The treatment cost has an impact on the satisfaction of the inpatients of public hospitals in Bangladesh. In HCMC, outpatient treatment cost has no impact on satisfaction with hospitals in general and public and private hospitals in particular.

One particular problem in this study is that the "treatment outcome" appears most important. This is a different result 
Table 5: Correlation matrix $(n=450)$

\begin{tabular}{|l|c|c|c|c|c|c|c|c|}
\hline & SAT & TAN & PRO & OUT & CARE & TIME & REL & COST \\
\hline SAT & $\mathbf{1 . 0 0 0}$ & $0.569^{* *}$ & $0.724^{* *}$ & $0.669^{* *}$ & $0.712^{* *}$ & $-0.273^{* *}$ & $0.500^{* *}$ & -0.091 \\
\hline TAN & 0.000 & $\mathbf{1 . 0 0 0}$ & $0.456^{* *}$ & $0.413^{* *}$ & $0.501^{* *}$ & $-0.130^{* *}$ & $0.344^{* *}$ & 0.006 \\
\hline PRO & 0.000 & 0.000 & $\mathbf{1 . 0 0 0}$ & $0.615^{* *}$ & $0.693^{* *}$ & $-0.276^{* *}$ & $0.548^{* *}$ & $-0.140^{* *}$ \\
\hline OUT & 0.000 & 0.000 & 0.000 & $\mathbf{1 . 0 0 0}$ & $0.591^{* *}$ & $-0.119^{*}$ & $0.378^{* *}$ & 0.000 \\
\hline CARE & 0.000 & 0.000 & 0.000 & 0.000 & $\mathbf{1 . 0 0 0}$ & $-0.273^{* *}$ & $0.523^{* *}$ & $-0.093^{*}$ \\
\hline TIME & 0.000 & 0.005 & 0.000 & 0.011 & 0.000 & $\mathbf{1 . 0 0 0}$ & $-0.112^{*}$ & $0.231^{* *}$ \\
\hline REL & 0.000 & 0.000 & 0.000 & 0.000 & 0.000 & 0.016 & 1.000 & -0.088 \\
\hline COST & 0.053 & 0.903 & 0.003 & 0.996 & 0.047 & 0.000 & 0.060 & $\mathbf{1 . 0 0 0}$ \\
\hline
\end{tabular}

** Spearman's correlation was statistically significant at 0.01 (2-tailed)

* Spearman's correlation was statistically significant at 0.05 (2-tailed)

Table 6: Regression model with full sample $(n=450)$

\begin{tabular}{|c|c|c|c|c|c|c|c|}
\hline \multirow{2}{*}{ Model } & \multicolumn{2}{|c|}{ Unstandardized coefficient } & \multirow{2}{*}{$\begin{array}{c}\begin{array}{c}\text { Standardized } \\
\text { coefficient }\end{array} \\
\text { Beta } \\
\end{array}$} & \multirow{2}{*}{$\mathbf{t}$} & \multirow{2}{*}{$\begin{array}{c}\text { Level of } \\
\text { Significance }\end{array}$} & \multicolumn{2}{|c|}{ Multicollinearity } \\
\hline & B & Standard error & & & & Tolerance & VIF \\
\hline (Constant) & -.0231 & 0.332 & & -0.696 & .487 & & \\
\hline TAN & 0.209 & 0.026 & 0.196 & 6.511 & .000 & 0.960 & 1.042 \\
\hline PRO & 0.297 & 0.024 & 0.269 & 6.437 & .001 & 0.951 & 1.051 \\
\hline OUT & 0.346 & 0.071 & 0.315 & 9.908 & .000 & 0.986 & 1.014 \\
\hline CARE & 0.180 & 0.039 & 0.178 & 4.714 & .001 & 0.939 & 1.065 \\
\hline TIME & -0.095 & 0.035 & -0.093 & -3.493 & .001 & 0.917 & 1.091 \\
\hline \multicolumn{2}{|c|}{ Adjusted $\mathrm{R}^{2}$} & \multicolumn{6}{|c|}{0.659} \\
\hline \multicolumn{2}{|c|}{ Durbin - Watson } & \multicolumn{6}{|c|}{2.073} \\
\hline \multicolumn{2}{|c|}{$\mathrm{F}$} & \multicolumn{6}{|c|}{165.7} \\
\hline \multicolumn{2}{|l|}{ sig } & \multicolumn{6}{|c|}{0.000} \\
\hline
\end{tabular}

compared to previous studies, particularly the satisfaction of outpatient study in Korea that primarily measures the functional factors of the service. The "outcome" scale of Sweeney et al (2007) has six components, of which only one is retained in this study. "Patients believe the hospital has brought the best treatment outcome". Unlike the study by Sweeney et al (2007), the "treatment outcome" factor is the most important factor in the model. The finding about "treatment time" at general hospitals in HCMC is consistent with the results of the study by Linh, Le, Empereur, \& Briançon (2002), a time-consuming medical examination that has a negative impact on patient satisfaction, which has long been presented and so far has not been overcome.

\subsection{Difference Testing}

The purpose of this analysis is to find differences in the quality of service assessment by factors such as gender, age, academic level, income and occupation. In this section, ANOVA and T-test are used to find differences in characteristics of respondents versus the satisfaction of quality of service. The results show that there is a difference in the quality of private general hospitals in HCMC services by gender - women, especially are more satisfied with the quality of service at Tiki.vn than men. There is a difference in satisfaction with the quality of private general hospitals in HCMC services by age. We found that, at the age of 50 to less than 60 , service quality satisfaction was highest, followed by the over 60 age group, 40 to less than 50 group, 30 to less than 40 group, 20 to less than 30 group. There is a difference in the satisfaction of service quality by income. We found that at a salary of from VND40 million up, the satisfaction of service quality was highest, followed by the decreasing income, and the group of no income has the lowest satisfaction of service quality. We also found that 
there is no difference in the satisfaction of service quality by educational level, by occupation, and between group of oupatients who were treated with and without health insurance (Giao \& Vuong, 2019).

\section{Conclusion and Management Suggestions}

\subsection{Management Suggestions}

In the trend of health socialization, the health care environment has changed, the administrators are under more pressure, the activists have to bring about the result which is not only professionally effective, but also financially effective and brand value. This research helps private hospital managers better understand the client's perspective and provides some tools to improve patient satisfaction with the hospital.

Firstly, this study shows that the treatment outcomes are the most important factor affecting outpatient satisfaction. This depends on the technical team, the technical means and the operation of the professional processes. In fact, there is no significant difference in outcomes between outpatient clinics in general-sized hospitals. Cured illness is the desire derived from human instinct, which does not change over time, and is also the primary goal of every hospital. Therefore, improving outpatient treatment outcomes is a must, but it is not a long-term competitive advantage between general hospitals. Strategically, private hospitals need to create a sense of satisfaction that is appreciated by patients and the community, thereby building a lasting relationship with the community.

Secondly, on the "doctors and nurses' professional capacity", this factor is formed by two groups: (1) professional competence, (2) communication capacity. The traditional view is often concerned only with the first group, so many of the patients' opinions reflecting on the attitudes of health care workers remain. Professional competence can be considered as a technical competence, while the basis of communicative competence is the attentive and sincere attention of the physician and the nurse to the patient, and soft skills are extremely important to increase patient satisfaction, thereby attracting customers to choose hospitals for health care. Therefore, the private hospital needs to have a reasonable staffing policy and ensure consistent and appropriate implementation of the policy, which requires time, cost, consensus in the organization, and the heart of hospital management (Giao \& Khanh, 2018).

Thirdly, other factors influence patient satisfaction, such as hospital facilities and environment, patient care, time saved for patients, etc. should perform synchronously to achieve high resonance. One thing to note, the cost of outpatient care does not have an impact on outpatient satisfaction, but Vietnam is classified in middle-income category, people have sensitivity to cost when deciding on a hospital, managers should develop a pricing policy that is appropriate for the private hospital's target customers.

\subsection{Conclusion}

This study has achieved its initial goal of developing and validating scales of factors that affect outpatient satisfaction, and developing and validating an outpatient satisfaction model at private general hospitals in HCMC. This research aims to provide private hospital managers with appropriate approaches to improve outpatient satisfaction, thereby maintaining a good relationship with the community and bring effectiveness for the hospital. This study has developed a range of factors affecting outpatient satisfaction in general hospitals in HCMC. In the general model, five factors influence the satisfaction of outpatients in private general hospitals: the hospital's infrastructure and environment; doctors and nurses'qualifications, hospital care for patients, treatment outcome, and treatment time. This study is based on the outpatient's point of view; the outpatient's perception of quality of care is always limited. The model in this study reflects the large number of low and middle-income outpatients, then, a model for high-income groups should be developed in the future. This study may serve as a basis for the study of repeat use behaviors, hospital choice behaviors, or price acceptability in outpatient clinics. In addition, the inpatient satisfaction model should be developed separately.

\subsection{Limitations of the Research}

Limitations of the study are as follows: (1) the study was conducted at the top five private general hospitals in HCMC, so its representativeness is not high, it is difficult to generalize the findings to the whole community of private hospitals; (2) the target of this study are outpatients who were treated at the top five private general hospitals in HCMC, so there will be limitations in offering solutions to all patients; (3) the study was conducted in the last quarter of 2019 when patients had no experience towards the corona virus pandemy 2019 , so that the evaluation was in normal conditions; (4) the results only explain $65.9 \%$ of the variable value of the service quality at the top five private general hospitals in HCMC, this proves that there are other factors that affect the quality of service delivered, which this study has not mentioned. These limitations call for further research directions.

\section{References}

Andaleeb, S. S., Siddiqui, N., \& Khandakar, S. (2007). Patient satisfaction with health services in Bangladesh. Oxford, UK: Oxford University Press. 
Andaleeb, S. S., \& Conway, C. (2006). Customer satisfaction in the restaurant industry: an examination of the transaction-specific model. Journal of Services Marketing, 20(1), 3-11.

Anderson, E. W., Fornell, C., \& Lehmann, D. F. (1994). Customer satisfaction, market share, and profitability: Findings from Sweden. Journal of Marketing, 58(3), 53-66.

Babakus, E., \& Boller, G. W. (1992). An Empirical Assessment of the SERVQUAL Scale. Journal of Business Research, 24, 253268.

Babakus, E., \& Mangold, W. G. (1992). Adapting the SERVQUAL scale to hospital services: an empirical investigation. Health Sciences Research, 26(2), 767-786.

Baker, J. A., \& Lamb, C. W. (1993). Managing architectural design service quality. Journal of Professional Services Marketing, 10(1), 89-106.

Bartels, F., Giao, H. N. K., \& Ohlenburg, T. J. (2006). ASEAN Multinational Entreprises: A Structural Analysis of Strategic Coherence. ASEAN Economic Bulletin, 23(2), 171-191. DOI: 10.31219/osf.io/eqfuw.

Bei, L. T. (2001). An integrated model for the effects of perceived product, perceived service quality and perceived price fairness on customer satisfaction and loyalty. Journal of Customer Satisfaction, Dissatisfaction and Complain Behavior, 14, 125140.

Breja, S. K., Banwet, D. K., \& Iyer, K. C. (2011). Quality strategy for transformation: A case study. The TQM Journal, 23(1), 520. http://dx.doi.org/10.1108/17542731111097452

Carman, J. M. (1990). Consumer perceptions of service quality: An assessment of the SERVQUAL dimensions. Journal of Retailing, 66, 33-55.

Choe, B., Lee, D., \& Yoon, S. (2012). A multi-item measurement scale of healthcare service quality: an evaluation indicator of healthcare certification. Journal of Korean Social Quality Management, 40(3), 381-393.

Choi, K., Cho, W., Lee, S., Lee, H., \& Kim, C. (2004). The relationship among quality, value, satisfaction and behavioral intention in health care provider choice: a South Korean study. Journal of Business Research, 57, 913-921.

Cronin, J. J., \& Taylor, S. A. (1992). Measuring service quality: a reexamination and extension. Journal of Marketing, 56, 55-68.

Cronin, J. J., Brady, M. F., \& Hult, G. M., (2000). Assessing the Effects of Quality, Value, and Customer Satisfaction on Consumer Behavioral Intentions in Service Environments. Journal of Retailing, 76(2), 193-218.

Dabholkar (1995). The convergence of customer satisfaction and service quality evaluations with increasing customer patronage. Journal of Consumer Satisfaction, Dissatisfaction and Complaining Behavior, 8, 32-43.

Department of Health HCMC. (2020a). List of healthcare units in HCMC. Retrieved Feb 20, 2020 fromhttp://www. medinet.hochiminhcity.gov.vn/co-so-y-te/danh-sach-co-so-yte-c4636-898.aspx.
Department of Health HCMC. (2020b). Retrieved Feb 20, 2020 from http://www.medinet.hochiminhcity.gov.vn/benh-vien/ketqua-danh-gia-chat-luong-benh-vien-thuoc-nganh-y-te-tphcmnam-2019-c16308-22365.aspx.

Freeman, K. D., \& Dart, J. (1993). Measuring the perceived quality of professional business services. Journal of Professional Services Marketing, 9(1), 27-47.

Giao, H. N. K., \& Vuong, B. N. (2019). Giáo trình Cao hoc Phuong pháp Nghiên cưu Khoa học trong Kinh doanh- Cập nhật SmartPLS. Nhà xuất bản Tài chính. Hà Nội. DOI: 10.31219/osf.io/hbj3k.

Giao, H. N. K, Hoai, A. T., \& Vinh, P. Q. (2019). Quản trị Kinh doanh Dịch vu-Tù Góc nhìn Marketing. Nhà xuất bản Truyền thông Thông tin Hà Nội. DOI: 10.31219/osf. io/98hrd.

Giao, H. N. K. (2004). Marketing Dịch vụ-Mô hình 5 Khoảng cách Chất lượng Dịch vu. Nhà Xuất bản Thống kê.

Giao, H. N. K. (2017). Customer Satisfaction and Quality of Vietnam Airline Domestic Services. International Journal of Quality Innovation, 3(1), 1-11, DOI 10.1186/s40887-0170019-4

Giao, H. N. K. (2018e). Measuring service quality in construction project management service at AIC Management Co., Ltd. - A dimension-by-dimension analysis. International Journal of Applied Business and Economic Research, 16(1), 165-175. DOI: 10.31219/osf.io/bf5ke.

Giao, H. N. K. (2018f). Sách chuyên khảo Đo lường chất lương dịch vu tại Việt Nam- nhìn tù phía khách hàng. Nhà xuất bản Tài chính. Hà Nội. DOI: 10.31219/osf.io/cqh68.

Giao, H. N. K. (2019). Customer Satisfaction towards ATM Services: A Case of Vietcombank Vinh Long, Vietnam. Journal of Asian Finance, Economics and Business, 6(1), 141-148. http://doi.org/10.13106/jafeb.2019.vol6.no1.141

Giao, H. N. K. (2020). Customer Satisfaction at Tiki.vn E-Commerce Platform. Journal of Asian Finance, Economics and Business, 7(4), 173-183. https://doi.org/10.13106/jafeb.2020.vol7. no4.173

Giao, H. N. K., \& Ai, T. H. (2012). Tác động của chất lượng dịch vụ đến lòng trung thành của khách hàng sử dụng ADSL tại TPHCM. Tạp chí Phát triển Kinh tế, 256(Feb.), 34-44. DOI: 10.31219/osf.io/ ypxfm

Giao, H. N. K., \& Khanh, M. M. (2018). Các yếu tố ảnh hưởng đến sự hài lòng công việc của nhân viên bệnh viện đa khoa tỉnh Sóc Trăng. Tạp chí Kinh tế - Kỹ thuật Bình Dưong, 21(March), 1323. DOI: $10.31219 /$ osf.io/b2rm

Giao, H. N. K., \& Lien, L. T. P. (2018). The factors effect the English training at the foreign languages - Informatics Center, University of Banking, Ho Chi Minh City, Vietnam. Global and Stochastic Analysis, 5(6), 340-352. DOI: 10.31219/osf.io/ rnuad.

Giao, H. N. K., \& Mo, N. T. H. (2018). Factors influencing consumers' impulse television buying decision at Best Buy Vietnam (BBVN). Global and Stochastic Analysis, 5(6), 353369. DOI: $10.31219 /$ osf.io/cgz2x 
Giao, H. N. K., Vuong, B. N., \& Quan, T. N. (2019). The influence of website quality on consumer's e-loyalty through the mediating role of e-trust, satisfaction, and perceived enjoyment: An evidence from online shopping in Vietnam. Uncertain Supply Chain Management, 8(2), 351-370. DOI: 10.5267/j. uscm.2019.11.004.

Giao, H. N. K., Duong, P. N., \& Tu, T. N. (2018). Research on Consumer Behavior of Wine in HoChiMinh City. Global and Stochastic Analysis, 5(8), 111-122. DOI: 10.31219/osf. io/4cvn7.

Giao, H. N. K., Hoang, C. C., \& Vinh, P. Q. (2018). Factor affecting buying decision of Amalie lubricants in Vietnam. Global and Stochastic Analysis, 5(8), 137-150. DOI: 10.31219/osf.io/ $\operatorname{kgc56.}$

Giao, H. N. K., Kiem, D., Son, L. T., \& Dung, T. Q. (2018). Satisfaction of tourists to Hoi An ancient town, Vietnam. Global and Stochastic Analysis, 5(8), 123-136. DOI:10.31219/ osf.io/sbjev.

Giao, H. N. K., Trung, B., \& Truong, P. Q. (2019). Outbound service quality at Wan Hai Lines. Journal of Asian Finance, Economics and Business, 6(1), 177-185. http://doi.org/10.13106/ jafeb.2019.vol6.no1.177

Giao, H. N. K., Vuong, B. N., Huan, D. D., Tushar, H., \& Quan, T. N. (2020). The Effect of Emotional Intelligence on Turnover Intention and the Moderating Role of Perceived Organizational Support: Evidence from the Banking Industry of Vietnam. Sustainability, 12(5), 1857-1882. DOI: 10.3390/su12051857.

Giao, H. N. K., Hang, N. T. H., Phuong, N. N. D. Vuong, B. N., Tuan, H. Q., Vinh, P. Q., \& Tu, T. N. (2020). Giáo trình Cao hoc Quản trị Chiến luợc - Cập nhật BSC. Nhà xuất bản Tài chính. Hà Nội. ISBN: 978-604-79-2372-4

Grönroos, C. (1983). Strategic Management and Marketing in the Service Sector. Cambridge, MA: Marketing Science Institute.

Grönroos, C. (1984). A Service Quality Model and its Marketing Implications. European Journal of Marketing, 18(4), 36-44.

Grönroos, C. (1998). Marketing services: the case of a missing product. Journal of Business \& Industrial Marketing, 13(4/5), 322-338.

Hau L. N., Anh P. N. T., \& Thuy P. N. (2016). The effects of interaction behaviors of service frontliners on customer participation in the value co-creation: a study of health care service. Service Business, 11(2), 253-277. DOI: 10.1007/ s11628-016-0307-4

Huang, B., Wang, T., \& Xue, X. (2012). Service-selecting approach based on domain-specified 'Quality of Service' model and its application in logistics. The Service Industries Journal, 32(9), 1571-1588. http://dx.doi.org/10.1080/02642069.2010.551761

James, T. L., Calderon, E. D. V., \& Cook, D. F. (2017). Exploring patient perceptions of healthcare service quality through analysis of unstructured feedback. Expert Systems with Applications, 71, 479-492.

Kotler, P., \& Armstrong, G. M. (2004). Principles of Marketing. Upper Saddle River, NJ: Pearson/Prentice Hall.
Lee, D. (2017). HEALTHQUAL: a multi-item scale for assessing healthcare service quality. Service Business, 11(3), 491-516.

Linh, N. T. P., Le, T. G., Empereur, F., \& Briançon, S. (2002). Satisfaction level of patients hospitalised in Ho Chi Minh city, Vietnam. Santé Publique, 14(4), 345-360.

Liu, W.H., \& Xie, D. (2013). Quality decision of the logistics service supply chain with service quality guarantee. International Journal of Production Research, 51(5), 1618-1634. http:// dx.doi.org/10.1080/00207543.2012.720390

McElwee, G., \& Redman, T. (1993). Upward Appraisal in Practice: An Illustrative Example Using the Qualed Model. Education and Training, 35(2), 27-31.

Meesala, A., \& Paul, J. (2018). Service quality, consumer satisfaction and loyalty in hospitals: Thinking for the future. Journal of Retailing and Consumer Services, 40, 261-269

Mitropoulos, P., Vasileiou, K., \& Mitropoulos, I. (2018). Understanding quality and satisfaction in public hospital services: A nationwide inpatient survey in Greece. Journal of Retailing and Consumer Services, 40, 270-275.

Oliver, R. (1981). Measurement and Evaluation of Satisfaction Process in Retail Setting. Journal of Retailing, 57, 25-48.

Parasuraman, A., Zeithaml, V., \& Berry, L. (1985). A Conceptual Model of Service Quality and Its Implications for Future Research. Journal of Marketing, 49, 41-50.

Parasuraman, A., Zeithaml, V., \& Berry, L. (1988). SERVQUAL: A Multi-Item Scale for Measuring Consumer Perception of Service Quality. Journal of Retailing, 64(1), 12-40.

Parasuraman, A., Zeithaml, V., \& Berry, L. (1994). Reassessment of expectation as a comparison standard in measuring service quality: Implication for future research. Journal of Marketing, $58,111-124$.

Ranjbar, E., Zare, A., Arab, M., Nasiri, S., Hataminasab, S., \& Bahrami, M. (2012). Analysis of SERVQUAL in Shahid Sadoghi hospital, Yazd, Iran. Hormozgan Medicin Journal, 16(4), 333-340.

Rizan, M. (2010). Analysis of service quality and customer satisfaction, and its influence on customer loyalty. Oxford Business \& Economics Conference Program.

Solayappan, A., Jayakrishnan, J., \& Velmani, S. (2011). Quality measurement for hospital services. International Proceedings of Economics Development and Research, 12, 246-250.

Spreng, R. A., \& Singh, A. K. (1993). An empirical assessment of the servqual scale and the relationship between service quality and satisfaction. In D.W. Cravens \& P. Dickson: 1993 AMA Educators' Proceedings (pp. 1-6). Chicago, IL: American Marketing Association.

Strandvik, T., \& Liljander, V. (1994). A Comparison of Episode performance and relationship performance for a discrete service. Paper presented at the $3^{\text {rd }}$ Service Marketing Workshop, Berlin, Germany, 25-26 February.

Sweeney, J. C., Dagger, T., \& Johnson, L. W. (2007). A Hierarchical Model of Health Service Quality: Scale Development and 
Investigation of an Integrated Model. Journal of Service Research, 10(2), 123-142.

Teas, R. K. (1993). Expectations, Performance, Evaluation, and Consumers' Perception of Quality. Journal of Marketing, 57(4), 18-34.

Toptphcm. (2020). The best private hospital in Ho Chi Minh City. Retrieved Feb 20, 2020 from https://top10tphcm.com/top-benhvien-tu-nhan-tot-nhat-tai-tp-ho-chi-minhhttps://top10tphcm. com/author/jes.

Vietnam+. (2020). The push for the private health system to make a spectacular breakthrough. http://tuyengiao.vn/y-te-cong-dong/ nhung-cu-hich-de-he-thong-y-te-tu-nhan-but-pha-ngoan-muc125924Retrieved Feb 20, 2020 from https://www.vietnamplus. vn/nhung-cu-hich-de-he-thong-y-te-tu-nhan-but-pha-ngoanmuc/613309.vnp
Vogus, T. J., \& McClelland, L. E. (2016). When the customer is the patient: Lessons from healthcare research on patient satisfaction and service quality ratings. Human Resource Management Review, 26(1), 37-49.

Vuong, B. N., \& Giao, H. N. K. (2019). The impact of brand globalness on consumers purchase intention and the moderating role of consumer ethnocentrism an evidence from Vietnam. Journal of International Marketing, 32(1), 47-68. DOI: 10.1080/08961530.2019.1619115.

World Health Organization (2000). Client Satisfaction Evaluation. Workbook 6

Zeithaml, V.A., Berry, L. L., \& Parasuraman, A. (1993). Nature and Determinants of Customer Expectations of Service. Journal of the Academy of Marketing Science, 21(1), 1-12.

Zeithaml, V. A., \& Bitner, M. J. (1996), Services marketing. New York: McGraw Hill. 